Т. В. Колесник, О. В. Смольянова

ДЗ “Дніпропетровська медична академія МОЗ України”, м. Дніпро

\title{
ВИКОРИСТАННЯ МАЙСТЕР-КЛАСІВ ДЛЯ ФОРМУВАННЯ НАВИЧОК ВИКОНАННЯ МЕДИЧНИХ МАНІПУЛЯЦИЙ НА КАФЕДРІ ПРОПЕДЕВТИКИ ВНУТРІШНЬОЇ МЕДИЦИНИ
}

\author{
T. V. Kolesnyk, O. V. Smolianova \\ Dnipropetrovsk Medical Academy of Health Ministry of Ukraine, Dnipro

\section{MASTER CLASSES USING FOR MEDICAL MANIPULATIONS SKILLS DEVELOPMENT AT THE DEPARTMENT OF PROPAEDEUTICS OF INTERNAL MEDICINE}

\begin{abstract}
Мета роботи - висвітлити досвід застосування майстер-класів як самостійної роботи студентів на кафедрі пропедевтики внутрішньої медицини Дз “Дніпропетровська медична академія МОЗ України”.

Основна частина. Об’єктом даного дослідження є майстер-клас як позааудиторна форма організації самостійної роботи студентів. У статті розглянуто особливості організації майстер-класів для формування навичок виконання медичних маніпуляцій на кафедрі пропедевтики внутрішньої медицини ДЗ “Дніпропетровська медична академія МОЗ України”.

У статті запропоновано новий алгоритм проведення майстер-класів для формування професійної компетентності майбутнього лікаря - “навички виконання медичних маніпуляцій”. Відзначено роль асистента кафедри, який бере активну участь у залученні студентів до нових форм позааудиторної роботи.

Висновки. Формування висококваліфікованого фахівця у галузі знань “Охорона здоров’я”, особливо за спеціальністю “Медицина”, неможливе без повного оволодіння усіма компетентностями, які заплановані відповідним стандартом освіти. А саме високий та безпечний рівень оволодіння навичками виконання медичних маніпуляцій забезпечується за допомогою симуляційної освіти, зокрема майстер-класів.
\end{abstract}

Ключові слова: інноваційні методи навчання; практичні навички; студенти; внутрішня медицина.

The aim of the work - to highlight the experience of master classes using as students' independent work at the Department of Propaedeutics of Internal Medicine of Dnipropetrovsk Medical Academy of the Ministry of Health of Ukraine.

The main body. The object of this study is the master class as a extracurricular form of organization of students' independent work. The article considers peculiarities of master classes organization for the formation of the skills of performing medical manipulations at the Department of Propaedeutics of Internal Medicine of Dnipropetrovsk Medical Academy of the Ministry of Health of Ukraine.

The article proposed a new master classes algorithm for the professional competence formation by future physician for the implementation of medical manipulations. The role of the assistant of the department, who takes an active part in attracting students to new forms of extracurricular work is noted.

Conclusions. The formation of a highly skilled specialist in the field of Health care, especially in the specialty of Medicine, is impossible without full mastery of all competencies that are planned by the relevant standard of education. The high and safe level of mastering skills of performing medical manipulations is impossible without the use of simulation in education, in particular, master classes.

Key words: innovative teaching methods; practical skills; students; internal medicine.

Вступ. Сучасна система вищої медичної освіти України орієнтована, в першу чергу, на формування у майбутніх лікарів відповідних професійних компетенцій. Процес отримання медичної освіти має бути ефективним та безпечним для всіх учасників, зокрема пацієнтів, що може бути забезпечене завдяки використанню симуляційного навчання.

Медична освіта на основі моделювання чи симуляції може впровадити безпечні методи та знизити шкоду для пацієнтів. Через це симуляційна освіта має стати невід'ємною частиною створення безпечної системи охорони здоров'я для пацієнтів [1-3].

Серед фахових компетентностей, якими потрібно оволодіти майбутнім лікарям, є “навички виконання медичних маніпуляцій”, зокрема виконання внутрішньовенних та внутрішньом'язових ін'єкцій [4]. Симуляційне навчання практичних навичок, за даними систематичного огляду, поліпшує технічні

(c) Т. В. Колесник, О. В. Смольянова 
характеристики клініцистів, особливо під час критичних подій та складних процедур [5]. За даними анкетування студентів, лише половина випускників медичних вузів вважає підготовку щодо формування практичних навичок під час занять на кафедрах достатньою [6].

Одним із шляхів вирішення цієї проблеми є використання майстер-класів для формування відповідних практичних навичок у якості позааудиторного навчання в рамках самостійної роботи студентів.

Мета роботи - висвітлити досвід застосування майстер-класів як самостійного виду роботи студентів на кафедрі пропедевтики внутрішньої медицини Дз “Дніпропетровська медична академія МO3 України”.

Основна частина. Майстер-клас дає можливість інтерактивної участі слухачів та наближає студента до належної лікарської практики згідно з протоколами надання медичної допомоги [7]. Доведено, що студенти після проведення майстер-класу мають більш високий рівень оволодіння практичними навичками [8].

Традиційний алгоритм проведення майстер-класів включає такі етапи: I етап - презентація педагогічного досвіду майстра; II етап - визначення основних прийомів роботи, які будуть демонструвати; III етап - проведення імітаційної гри; IV етап моделювання, при якому учасники майстер-класу конструюють власну модель навчального заняття в режимі технології педагога-майстра; V етап рефлексія на основі результатів спільної діяльності педагога-майстра і учасників майстер-класу [9].

Традиційний алгоритм майстер-класів орієнтований більш за все на використання його в педагогіці. Ми, задля більшої наближеності до реальних проблем формування практичних навичок, використали такий алгоритм:

1 етап - теоретичне обгрунтування навички виконання медичної маніпуляції;

2 етап - практична демонстрація викладачем навички виконання медичної маніпуляції на манекені;

3 етап - моделювання, при якому учасники майстер-класу на манекені формують навички виконання медичної маніпуляції, а досвідчений викладач контролює кожного та виправляє помилки, які виникають;

4 етап - обговорення вражень та типових помилок при виконанні медичної маніпуляції.

Майстер-клас проводили у лекційній аудиторії, і оскільки він був організований в рамках самостійної позааудиторної роботи студентів, то від- відування було добровільним. Інформація щодо часу та місця проведення майстер-класу була розповсюджена за допомогою сторінки Студентської ради Д3 “Дніпропетровська медична академія МO3 України” в мережах Facebook та Instagram, а також за допомогою об’яв на інформаційних стендах навчальних корпусів та гуртожитків.

На майстер-клас прийшли 95 студентів 2-6 курсів I та II медичних факультетів. Ведучим майстеркласу був керівник студентського наукового товариства кафедри. Досвід керівництва студентським науковим товариством дозволяє ведучому більш доступно та неформально підходити до проведення майстер-класу.

Після пояснення теоретичних основ виконання внутрішньовенних та внутрішньом'язових ін'єкцій студенти змогли на манекенах практикуватися у техніці виконання ін'єкцій. Ведучий майстер-класу використовував періодичний високочастотний зворотний зв’язок (корекція неправильного виконання після кожної спроби). Відомо, що саме високочастотний зворотний зв'язок приводить до кращого виконання медичних маніпуляцій [10], що й ставилося на меті при організації майстер-класу. Після того як кожний присутній досяг успіху у виконанні ін'єкцій, ведучий розібрав, разом з аудиторією, типові помилки.

Проте варто відмітити деякі складнощі, що виникли у проведенні майстер-класу: варто обмежувати одночасну кількість студентів на майстер-класі по 2-3 студенти на манекен; це можливо при використанні попереднього запису на майстер-клас. Доцільно краще залучати студентів міжнародних факультетів до участі у майстер-класі, з можливою організацією таких заходів у форматі лише для іноземних студентів, залучаючи до організації органи студентського самоврядування, земляцтва тощо.

Висновки. Використання майстер-класу для формування навичок виконання медичних маніпуляцій, зокрема внутрішньовенних та внутрішньом'язових ін'єкцій, є доцільною та ефективною формою організації самостійної позааудиторної роботи студентів. Майстер-клас є актуальною формою розповсюдження симуляційних методик для використання їх у підготовці фахівців у галузі знань “Охорона здоров’я”, особливо за спеціальністю “Медицина”. Завдяки такій формі організації самостійної позааудиторної роботи студентів можливий високий та безпечний рівень оволодіння усіма компетентностями, які заплановані відповідним стандартом освіти. 


\section{Список літератури}

1. Training and simulation for patient safety / R. Aggarwal, O. T. Mytton, M. Derbrew [et al.] // Quality and Safety in Health Care. - 2010. - Vol. 19, Suppl 2. - P. i34-i43.

2. Організація симуляційного навчання у ДВНЗ “Тернопільський державний медичний університет імені I. Я. Горбачевського МОЗ України” / М. М. Корда, А. Г. Шульгай, А. А. Гудима, С. Й. Запорожан // Медична освіта. - 2017. - № 3. - С. 22-26.

3. Контроль ефективності засвоєння практичних навичок випускниками Донецького національного медичного університету за спеціальністю “Медицина” / Ю. В. Думанський, П. Г. Кондратенко, М. В. Конькова, О. В. Кєтінг // Медична освіта. - 2017. - № 3. - С. 46-47.

4. Максименко С. Д. Педагогіка вищої медичної освіти / С. Д. Максименко, М. М. Філоненко. - К. : Центр учбової літератури, 2014. - 288 с.

5. Simulation exercises as a patient safety strategy: a systematic review / E. Schmidt, S. N. Goldhaber-Fiebert,

\section{References}

1. Aggarwal, R., Mytton, O. T., Derbrew, M., Hananel, D., Heydenburg, M., Issenberg, B., ... Reznick, R. (2010). Training and simulation for patient safety. Quality and Safety in Health Care, 19 (2), i34-i43. https://doi.org/10.1136/ qshc.2009.038562.

2. Korda, M.M., Shulhai, A.H., Hudyma, A.A., \& Zaporozhan, S.Y. (2017). Orhanizatsiia symuliatsiinoho navchannia u DVNZ “Ternopilskyi derzhavnyi medychnyi universytet imeni I.Ya. Horbachevskoho MOZ Ukrainy”. [Simulation training organization at I. Horbachevsky Ternopil State Medical University]. Medychna osvita - Medical Education, (3), 22-26. Retrieved from: https://doi. org/10.11603/me.2414-5998.2017.3.7759 [in Ukrainian].

3. Dumanskyi, Yu.V., Kondratenko, P.H., Konkova, M.V., \& Kietinh, O.V. (2017). Kontrol efektyvnosti zasvoiennia praktychnykh navychok vypusknykamy donetskoho natsionalnoho medychnoho universytetu za spetsialnistiu “Medytsyna” [Performance management of learning practical skills by Donetsk national medical university graduates with a specialization in Medicine]. Medychna osvita - Medical Education, (3), 46-47. Retrieved from: https://doi.org/10.11603/me.2414-5998.2017.3.7774 [in Ukrainian].

4. Maksymenko, S.D., \& Filonenko, M.M. (2014). Pedahohika vyshchoi medychnoi osvity [Pedagogy of higher medical education]. Kyiv: Tsentr uchbovoi literatury [in Ukrainian].

5. Schmidt, E., Goldhaber-Fiebert, S.N., Ho, L.A., \& McDonald, K.M. (2013). Simulation exercises as a patient safety strategy: a systematic review. Annals of Internal
L. A. Ho, K. M. McDonald // Annals of Internal Medicine. - 2013. - Vol. 158, No. 5 (2). - P. 426.

6. Шляхи підвищення якості навчання на підставі моніторингу анкетування випускників академії / Г. В. Дзяк, Т. О. Перцева, С. В. Захаров, Г. В. Горбунова // Медична освіта. - 2015. - № 2. - С. 64-66.

7. Галюк Н. М. Майстер-клас як нова форма професійної підготовки лікарів / Н. М. Галюк // Буковинський медичний вісник. - 2013. - Т. 17, № 2. - С. 212-214.

8. Галюк Н. М. Майстер-клас як нова форма організації навчального процесу / Н. М. Галюк // Буковинський медичний вісник. - 2015. - Т. 19, № 1. - С. 247-249.

9. Мухлынина Т. В. Методические рекомендации по проведению мастер-класса / Т. В. Мухлынина, О. В. Фадеенко. - СПб., 2016. - 20 с.

10. The benefit of repetitive skills training and frequency of expert feedback in the early acquisition of procedural skills / H. M. Bosse, J. Mohr, B. Buss [et al.] // BMC Medical Education. - 2015. - Vol. 15, No. 1. - P. 15-22.

Medicine, 158 (5_2), 426. Retrieved from: https://doi. org/10.7326/0003-4819-158-5-201303051-00010.

6. Dziak, H.V., Pertseva, T.O., Zakharov, S.V., \& Horbunova, H.V. (2015). Shliakhy pidvyshchennia yakosti navchannia na pidstavi monitorynhu anketuvannia vypusknykiv akademii [Quality improving ways of education based on monitoring of academy graduates' survey]. Medychna osvita - Medical Education, (2), 64-66 [in Ukrainian].

7. Haliuk, N.M. (2013). Maister-klas yak nova forma profesiinoi pidhotovky likariv [Master class as a new form of professional training doctors]. Bukovynskyi medychnyi visnyk - Bukovinian Medical Herald, 17 (2), 212-214 [in Ukrainian].

8. Haliuk, N.M. (2015). Maister-klas yak nova forma orhanizatsii navchalnoho protsesu [Master class as a new form of the educational process organization]. Bukovynskyi medychnyi visnyk - Bukovinian Medical Herald, 19 (1), 247-249 [in Ukrainian].

9. Mukhlynina, T.V., \& Fadeyenko, O.V. (2016). Metodicheskie rekomendatsii po provedeniyu master-klassa [Methodical recommendations for a master class conducting]. Saint-Petersburg. Retrieved from: http://dumspb.ru/ sites/default/files/razdatka_dlya_pdo_mk.pdf [in Russian].

10. Bosse, H.M., Mohr, J., Buss, B., Krautter, M., Weyrich, P., Herzog, W., ... Nikendei, C. (2015). The benefit of repetitive skills training and frequency of expert feedback in the early acquisition of procedural skills. BMC Medical Education, 15 (1), 15-22. DOI: https://doi.org/10.1186/ s12909-015-0286-5. 